\title{
Register to donate while you wait: Assessing public opinions of the acceptability of utilizing the emergency department waiting room for organ and tissue donor registration
}

\author{
Brittany Ellis, MD, MSc ; Michael Hartwick, MD, MEd ${ }^{\dagger \ddagger} ;$ Jeffrey J. Perry, MD, MSc ${ }^{*} \S \Phi$
}

\section{CLINICIAN'S CAPSULE}

What is known about the topic?

Only one-third of Ontario residents are registered to donate organs. However, in Canada, the need for organs outstrips supply.

What did this study ask?

This survey asked patients/visitors in an emergency department (ED) waiting room about information and registration for organ donation in the ED.

What did this study find?

This survey found ED patients/visitors are supportive obtaining organ donation information, and many would consider registering while waiting.

Why does this study matter to clinicians?

Providing information and opportunities to register for organ donation in the ED may further promote organ donation registration in Canada.

\section{ABSTRACT}

Objective: Our objectives were to identify barriers to the organ donation registration process in Ontario; and to determine the acceptability of using the emergency department (ED) waiting room to provide knowledge and offer opportunities for organ and tissue donor registration.

Methods: We conducted a paper based in-person survey over nine days in March and April 2017. The survey instrument was created in English using existing literature and expert opinion, pilot tested and then translated into French. Data was collected from patients and visitors in an urban academic Canadian tertiary care ED waiting room. All adults in the waiting room were approached to participate during study periods.
We excluded patients who were too ill and required immediate treatment.

Results: The number of attempted surveys was 324; 67 individuals $(20.7 \%)$ declined participation. A total of 257 surveys were distributed and five were returned blank. This gave us a response rate of $77.8 \%$ with 252 completed surveys. The median age group was $51-60$ years old with $55.9 \%$ female. Forty-six percent reported their religion as Christian and $34.1 \%$ did not declare a religious affiliation. $44.1 \%$ were already registered donors. Most participants agreed or were neutral that the ED waiting room was an acceptable place to provide information on donation, and for registration as an organ and tissue donor (83.3\% and $82.1 \%$, respectively).

Conclusions: Individuals waiting in the ED are generally supportive of using the waiting room for distributing information regarding organ and tissue donation, and to allow donor registration.

\section{RÉSUMÉ}

Contexte: L'étude avait pour objectifs : 1) de relever les obstacles au processus d'inscription du don d'organes en Ontario; 2) de déterminer l'acceptabilité sociale de I'utilisation de la salle d'attente du service des urgences (SU) comme lieu de diffusion de l'information sur les dons de matériel biologique, et $d^{\prime}$ inscription de donneurs d'organes et de tissus.

Méthode: Une enquête a été menée en personne, au moyen d'un questionnaire sur papier, durant 9 jours, en mars et en avril 2017. L'instrument d'enquête a d'abord été élaboré en anglais à l'aide de la documentation existante et de l'avis d'experts, puis soumis à un essai pilote avant d'être traduit en français. La collecte de données s'est faite parmi les patients et les personnes qui les accompagnaient dans une salle d'attente d'un SU d'enseignement, de soins tertiaires, situé en milieu

From *Department of Emergency Medicine, University of Ottawa, Ottawa, ON; tDepartment of Medicine Divisions of Critical Care and Palliative Medicine, University of Ottawa, Ottawa, ON; ‡Regional Medical Lead, Trillium Gift of Life Network, Toronto, ON; §School of Epidemiology, Public Health and Preventative Medicine, University of Ottawa, Ottawa, ON; and the Ithe Clinical Epidemiology Program, Ottawa Hospital Research Institute, Ottawa, ON.

Correspondence to: Dr. Brittany Ellis, Ottawa Hospital, Civic Campus, Dept. of Emergency Medicine, 1053 Carling Ave., Ottawa, ON K1Y 4E9; Email: brellis@toh.ca

(C) Canadian Association of Emergency Physicians

CJEM 2019;21(5):622-625

DOI 10.1017/cem.2019.347 
urbain, au Canada. Tous les adultes présents dans la salle d'attente ont été invités à participer à l'étude durant la période en question. Ont été exclus les patients qui étaient trop malades ou dont l'état nécessitait des soins immédiats.

Résultats: II y a eu 324 demandes d'enquête et 67 personnes $(20,7 \%)$ ont refusé de participer. Sur un total de 257 questionnaires remis, 5 ont été rendus vierges, ce qui a porté à $77,8 \%$ (252 questionnaires remplis) le taux de réponse. L'âge médian était de 51-60 ans, et 55,9\% des répondants étaient des femmes. Quarante-six pour cent des participants se sont déclarés chrétiens et $34,1 \%$ n'ont rien indiqué quant à leur appartenance religieuse; par ailleurs, $44,1 \%$ étaient déjà des donneurs inscrits. La plupart des répondants se sont montrés favorables ou neutres à l'égard de l'utilisation de la salle d'attente du SU comme lieu de diffusion de l'information sur les dons de matériel biologique, ou d'inscription de donneurs d'organes et de tissus $(83,3 \%$ et $82,1 \%$, respectivement).

Conclusion: Dans l'ensemble, les personnes interrogées au SU se sont montrées favorables à l'utilisation de la salle $\mathrm{d}^{\prime}$ attente comme lieu de diffusion de l'information sur les dons d'organes et de tissus, et d'inscription de donneurs.

Keywords: Emergency department, organ and tissue donation

\section{INTRODUCTION}

Canada operates an "opt-in" approach to organ and tissue donation, whereby citizens can register to become a donor. Nationally, $96 \%$ of Canadians support organ or tissue donation; however, only $17 \%$ are registered. ${ }^{1}$ This suggests a disconnect between potential donors and the registration process.

Characteristics of registered donors versus unregistered individuals have been reported $^{2,3}$; however, research into barriers surrounding the registration process in Canada is lacking. Data are lacking regarding the use of high-volume health care spaces such as emergency departments (ED) to facilitate donor registration.

Our objectives were to conduct an ED waiting roombased survey to: 1) identify barriers to organ and tissue donation registration in Ontario; and 2) determine the acceptability of utilizing an ED waiting room to provide organ and tissue donation information and for donation registration.

\section{METHODS}

\section{Study design}

We conducted a paper-based survey in an urban Canadian academic ED with 230 daily visits. Participants were aged over 16 years, able to communicate in French or English, and were present in the waiting room during pre-defined data collection periods. Individuals arriving in the waiting room and their accompanying family or friends were eligible for participation. Patients sent directly to high-acuity areas were ineligible.

\section{Survey development}

Following a review of the existing literature, a draft survey was developed. It was piloted in 10 non-medical volunteers, who were asked about readability, language, and structure. Each person read questions and answers aloud, and any difficulties were probed by the principal investigator. The final survey was translated into French by a certified translator. We asked 15 questions including age, sex, religion, province, knowledge on how to register for donation, desire for information on organ donation, and donor status. We assessed agreement with six statements about organ donation (using a five-point Likert scale). The statements assessed information needs: if the ED is acceptable to obtain information or to register as an organ donor. A list of seven potential barriers was provided, in addition to free space response areas, to report additional barriers and comments.

\section{Data collection}

The survey was conducted from March to April 2017 between 15:00 and 21:00 hours on nine non-consecutive weekdays, based on the principal investigator's availability. Surveys, including a study information sheet, were distributed to individuals presenting to the ED by an ED registration clerk or the principal investigator. Consent was implied by completion of the survey. Approval was granted by the local Research Ethics Board.

\section{Data analysis}

Data were compiled using Microsoft Excel (Microsoft Corporation, Redmond, WA). We calculated descriptive statistics. The five-point Likert scale questions were 
grouped into agree (composite of agree and strongly agree), neutral, and disagree (composite of disagree and strongly disagree). Frequency tables were produced for each variable. A subgroup analysis was completed to determine if answers differed based on current donor status or age group. Our sample size was based on feasibility.

\section{RESULTS}

Three hundred twenty-four individuals were approached to participate. Sixty-seven $(20.7 \%)$ declined participation. Of the 257 surveys distributed; five were returned blank. This gave a response rate of $77.8 \%$ (252/324 surveys). Of these, 235 were fully completed; 17 had partial answers.

The median age group was 51-60 years old, and most participants were female (55.9\%) (Appendix 1). Christian religion (46.0\%) was most frequently reported, with over one-third (34.1\%) not declaring a religious affiliation. Further, $44.1 \%$ indicated they were registered as organ or tissue donors.

Many barriers to registering as a donor were identified (Appendix 2). The most common barriers reported were not knowing how to register (22.0\%), lack of time $(21.1 \%)$, and having unanswered questions (18.7\%). Some respondents $(16.3 \%)$ felt they were not eligible because of their current health, and $14.3 \%$ stated organ/tissue donation was against their personal or familial beliefs.

\section{Acceptability of utilizing the ED waiting room for organ/ tissue donation information or registration}

Of those who submitted the survey, $63.5 \%$ agreed that the ED waiting room was acceptable to provide donation information (Table 1). An additional $19.8 \%$ were neutral. Most agreed (62.3\%) or were neutral $(19.8 \%)$ that the $\mathrm{ED}$ was an acceptable place to register to become a donor; $47.2 \%$ would consider registering in the ED.

Of participants not registered as a donor, we found that $55.9 \%$ accepted the ED waiting room as an appropriate place to provide information regarding donation; $31.5 \%$ would consider registering in the waiting room (Appendix 3). This support for the distribution of information and ED donor registration persisted across all age groups.

\begin{tabular}{|c|c|}
\hline Questions regarding organ donation & $\begin{array}{l}\text { Respondents } \\
\text { No. (\%) }\end{array}$ \\
\hline \multicolumn{2}{|c|}{ I have questions regarding organ donation } \\
\hline Agree & $69(27.4)$ \\
\hline Neutral & $78(31.0)$ \\
\hline Disagree & $100(39.7)$ \\
\hline \multicolumn{2}{|c|}{$\begin{array}{l}\text { My questions regarding organ donation have } \\
\text { delayed registration as a donor }\end{array}$} \\
\hline Agree & $27(10.7)$ \\
\hline Neutral & $62(24.6)$ \\
\hline Disagree & $150(59.5)$ \\
\hline \multicolumn{2}{|c|}{$\begin{array}{l}\text { My family/friends are aware of my wishes regarding } \\
\text { organ donation }\end{array}$} \\
\hline Agree & $146(57.9)$ \\
\hline Neutral & 39 (15.5) \\
\hline Disagree & $59(23.4)$ \\
\hline \multicolumn{2}{|c|}{$\begin{array}{l}\text { The ED is an acceptable place to distribute } \\
\text { information on OD }\end{array}$} \\
\hline Agree & $160(63.5)$ \\
\hline Neutral & $50(19.8)$ \\
\hline Disagree & $35(13.9)$ \\
\hline \multicolumn{2}{|c|}{$\begin{array}{l}\text { The ED is an acceptable place to register as an organ } \\
\text { donor }\end{array}$} \\
\hline Agree & $157(62.3)$ \\
\hline Neutral & $50(19.8)$ \\
\hline Disagree & $38(15.1)$ \\
\hline \multicolumn{2}{|c|}{ I would consider registering as an OD in the ED } \\
\hline Agree & $119(47.2)$ \\
\hline Neutral & 40 (15.9) \\
\hline Disagree & $80(31.8)$ \\
\hline
\end{tabular}

\section{DISCUSSION/INTERPRETATION}

This study was the first to explore public perceptions of utilizing ED waiting rooms to promote organ and tissue donor registration. Participants identified modifiable barriers to registration, including not knowing how to register, having questions surrounding donation, and misconceptions regarding age or current health on eligibility. Additional barriers identified include having personal, religious, or familial beliefs that preclude registering as a donor.

The barriers identified in our study are in keeping with previous work surrounding organ and tissue donation. In 2005, a Canadian survey found the top three reasons for not registering as a donor included: having a medical condition (19\%), religious or spiritual beliefs 
(11\%), and personal preference or beliefs $(10 \%) .{ }^{5}$ In our survey, the top reason identified was medical conditions; however, a lack of time and knowledge of how to register was frequently reported. These changes could reflect changing societal preferences and changes to individual demands within the home and work environment.

Overall, participants supported using the ED waiting room for the distribution of information on, and the opportunity to register for, donation. Support was lower for non-registered participants; however, onethird said they would consider registering in the ED. The impact on registration for those who find the ED setting unacceptable is unclear.

Our study contextualizes issues previously studied on donor and registration issues, ${ }^{6,7}$ on which there is a lack of evidence within this specific Canadian setting. This study explores the presumption that the public may find it inappropriate to consider organ and tissue donation while in the ED. Over $20 \%$ of respondents identified a lack of time as a barrier to registration; as waiting is associated with most ED visits in Canada, the opportunity to learn and potentially register may be viewed as a welcome addition to clinical encounters. Further work in this area should include addressing the modifiable barriers identified in this study.

\section{Limitations}

Selection bias is a risk, given the study was a convenience sample and exclusively conducted during afternoons and evenings. As such, our participants may differ from those present at other times. Given that these times are correlated with the highest ED volumes, we believe the risk of this bias is small.

A second limitation pertains to possible response bias and the impact of social desirability. We found $44.1 \%$ of participants declared they were registered donors. This is higher than the reported $33 \%$ of Ontarians who are registered donors. ${ }^{4}$ It is possible that this discrepancy suggests a response bias or that the sample of people waiting in the ED represent individuals who are more likely to be registered donors.

Finally, the 67 individuals who declined participation and the five blank surveys may represent a non-response bias. It is unclear why they refused to participate; however, with our response rate at over $75 \%$, the potential impact of this bias is small.

\section{CONCLUSION}

Individuals in the ED waiting room are supportive of the distribution of information regarding organ and tissue donation. One-third of people not currently registered would consider registering to become a donor while in the waiting room. ED waiting rooms represent an opportunity to further organ and tissue donor awareness and registration. The potential impact on registration for participants who felt the ED waiting room was not an acceptable setting to receive organ donation registration information remains unclear. Further work in this area should include a trial of information provision and the opportunity to register as an organ donor while in the ED waiting room.

Acknowledgements: The author contributions were as follows: Dr. Ellis conceived the idea. Drs. Perry and Hartwick supervised the conduct of the project. All authors were involved in the discussions and planning of the project. Dr. Ellis drafted the manuscript, and all authors contributed substantially to its revision. Dr. Ellis takes responsibility for the paper as a whole.

Supplementary material: The supplementary material for this article can be found at https://doi.org/10.1017/cem.2019.347

Competing interests: The authors declare no conflicts of interest.

\section{REFERENCES}

1. Canadian Council for Donation and Transplantation (CAN). Public awareness and attitudes on organ and tissue donation and transplantation including donation after cardiac death final report. Canada, 2005; 131.

2. Rodrigue JR, Cornell DL, Howard RJ. Organ donation decision: comparison of donor and non-donor families. Amer $\mathcal{F}$ Transplant 2006;6(1):190-8.

3. Vincent A, Logan L. Consent for Organ Donation. Brit 7 Anes 2012;108(Suppl 1):i80-7.

4. Be a Donor. Registration Stats. Be a Donor; 2018. Available at: https://www.beadonor.ca/scoreboard (accessed November 1, 2018).

5. Canadian Council for Donation and Transplantation (CAN). Organ and tissue donation public opinion survey - topline summary report. Report PN5711. Canada, 2005; 7.

6. Wakefield CE, Watts KJ, Homewood J, Meiser B, Siminoff LA. Attitudes towards organ donation and donor behavior: A review of the international literature. Prog Transplant 2010; 20(4):380-91.

7. Irving MJ, Tong A, Jan S, et al. Factors that influence the decision to be an organ donor: a systematic review of the qualitative literature. Nephrol Dial Transplant 2012;27(6):2526-33. 